\title{
Potential Applications of Welan Gum in Upstream Petroleum Industry
}

\author{
Changhong Gao \\ Sinopec Shengli E\&P Research Center, Dongying, Shandong, China
}

\section{Email address:}

237184689@QQ.com

To cite this article:

Changhong Gao. Potential Applications of Welan Gum in Upstream Petroleum Industry. International Journal of Oil, Gas and Coal Engineering. Vol. 4, No. 2, 2016, pp. 16-23. doi: 10.11648/j.ogce.20160402.12

Received: February 14, 2016; Accepted: March 30, 2016; Published: May 4, 2016

\begin{abstract}
Welan gum (WLG) has been widely used in food industry as thickener. This paper studies its potential applications in upstream petroleum industry. Welan gum was added to drilling mud, and rheology tests were conducted to evaluate mud performance. Experiments demonstrate welan gum effectively boosts mud viscosity. WLG mud also shows strong stability under high temperature and high concentrations of salts. Welan gum has good potential as mud thickener. Rheology tests were also carried out for the aqueous solution of welan gum. Viscosity of WLG solution remained high after addition of sodium chloride and calcium chloride. Long term heating has limited effect on its viscosity. Recovery tests show welan gum can improve oil recovery, and speed up recovery process. Welan gum has good potential for enhanced oil recovery.
\end{abstract}

Keywords: Welan Gum, Drilling Mud, Oil Recovery, Polymer Rheology

\section{Introduction}

Drilling mud plays a vital role in the success of drilling operations. It cools and lubricates drill bit, controls well pressure, transports and suspends cuttings. Mud must have a relatively high viscosity in order to effectively suspend cuttings. Therefore mud thickeners are often added into mud to boost mud viscosity. The most widely used mud thickeners are carboxy methyl cellulose (CMC) and hedroxy ethyl cellulose (HEC) [1]. CMC and HEC are inexpensive, but their performances under high temperature and high salinity are compromised.

The oil field is put on production after wells are drilled. Even after primary recovery process and water flooding, large amount of oil remains in the reservoir. Scientists have developed methods to improve oil recovery by injection of steam, chemicals, and carbon dioxide [2,3]. Steam injection is the most effective EOR method for heavy oil, while polymer flooding is the most successful chemical EOR method. Large-scale polymer flooding projects have been carried out in China since 1990s [4]. For the commercial projects, HPAM (partially hydrolyzed polyacrylamide) has been the most widely used polymer for injection. Unfortunately, HPAM severely degrades under high salinity and high temperature [5]. This factor restricts the industrial adoption of polymer EOR method.

Welan Gum (WLG) is produced by fermentation of sugar by bacteria of the genus Alcaligenes. The molecule consists of repeating tetrasaccharide units with single branches of Lmannose or L-rhamnose [6]. The molecular structure is presented in Figure 1. It was reported that WLG exhibits good viscosity retention at elevated temperature, as well as in the presence of sodium chloride [7]. WLG is a widely used thickener in food industry. WLG was also patented as cement additive [8], as well as water shutoff chemical [9].

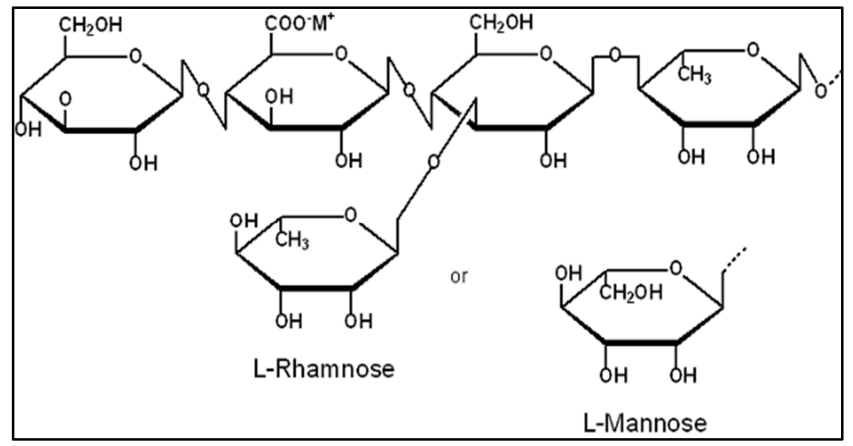

Figure 1. Molecular structure of Welan Gum. 
However, very limited research has been conducted to investigate the potential of WLG as a mud thickener, as well as its potential as a polymer for EOR. It would be ideal if welan gum finds multiple applications in upstream petroleum industry.

\section{Materials and Method}

\subsection{Drilling Mud Experiments}

Welan Gum was provided by BDL Chemical Company in China. CMC of medium viscosity was produced by Gumpro Chemical Company in India. Other materials including Bentonite clay, $\mathrm{NaCl}$, and $\mathrm{CaCl}_{2}$ were purchased from local suppliers. Mud was prepared by mixing clay into tap water with a high-speed mixer. Mud viscosity was measured with industry-standard mud viscometer. It measures the torque under 8 different rotational speeds, ranging from 3 to 600 $\mathrm{rpm}$. The readings can be easily translated into mud plastic viscosity, mud yield point, and mud apparent viscosity.
The test matrix is given in Tables 1. First, a base mud was prepared by mixing $25 \mathrm{~g}$ of bentonite clay into $500 \mathrm{~g}$ of fresh water. Then base mud viscosity was measured. The measurements of mud plastic viscosity (PV), yield point (YP), and apparent viscosity (AV) followed textbook and industry standards [10]. Secondly, the effect of WLG concentration on mud viscosity was investigated, by adding different dosage of WLG into the base mud. The third group of tests assessed WLG mud properties at elevated temperatures.

The fourth group of tests was designed to evaluate the performance of WLG mud under the influence of $\mathrm{NaCl}$. Besides, different dosages of $\mathrm{CaCl}_{2}$ were added to WLG mud and the mud viscosity was measured. Finally, WLG mud was held at $85^{\circ} \mathrm{C}$ for 6 hours to test the effect of aging on mud properties. For the purpose of comparison, CMC mud was also tested under the influences of sodium ion, calcium ion, and long-term heating, as given in Table 1.

Table 1. Summary of mud experiments.

\begin{tabular}{llllll}
\hline Test No. & Tested Mud & NaCl Concentration $(\mathbf{g} / \mathbf{L})$ & $\mathbf{C a C l}$ Concentration $(\mathbf{g} / \mathbf{L})$ & WLG Concentration $(\mathbf{g} / \mathbf{L})$ & Temperature $\left({ }^{\circ} \mathbf{C}\right)$ \\
\hline 1 & Base mud & 0 & 0 & 0 & 25 \\
2 & WLG mud & 0 & 0 & $0.25 ; 0.5 ;$ & $0.75 ; 1.0 ;$ \\
3 & WLG mud & 0 & 0 & 1 & 25 \\
4 & WLG mud & $50 ; 100 ; 150 ;$ & 0 & 1 & $25 ; 45 ; 65 ; 85 ;$ \\
5 & WLG mud & 150 & $10 ; 30 ; 50 ;$ & 1 & 25 \\
6 & WLG mud & 0 & 0 & 1 & 25 \\
7 & CMC mud & 0 & 0 & $0.5 ; 1.0 ;$ & $85^{\circ} \mathrm{C}$ for 6 hours \\
8 & CMC mud & $50 ; 100 ; 150 ;$ & 0 & 1 & 25 \\
9 & CMC mud & 150 & $10 ; 30 ; 50 ;$ & 1 & 25 \\
10 & CMC mud & 0 & 0 & 1 & 25 \\
\hline
\end{tabular}

Table 2. Summary of rheology and recovery matrix.

\begin{tabular}{|c|c|c|c|c|c|}
\hline $\begin{array}{l}\text { Test } \\
\text { Group }\end{array}$ & $\begin{array}{l}\text { WLG Concentration } \\
(\mathrm{g} / \mathrm{L})\end{array}$ & $\mathrm{NaCl}$ Concentration $(\mathrm{g} / \mathrm{L})$ & $\begin{array}{l}\mathrm{CaCl}_{2} \text { Concentration } \\
(\mathrm{g} / \mathrm{L})\end{array}$ & Temperature $\left({ }^{\circ} \mathrm{C}\right)$ & Objective of test \\
\hline 1 & $1 ; 2 ; 3 ; 5 ; 8$ & 0 & 0 & 85 & Effect of WLG concentration \\
\hline 2 & 3 & $10 ; 50 ; 100 ; 150$ & 0 & 50 & Effect of sodium \\
\hline 3 & 3 & 0 & $10 ; 30 ; 50$ & 50 & Effect of calcium \\
\hline 4 & 3 & 150 & 50 & $85^{\circ} \mathrm{C}$ for 6 hours & Effect of aging \\
\hline 5 & 1 & 150 & 50 & 85 & Oil recovery \\
\hline
\end{tabular}

Table 3. Properties of mud after ageing tests.

\begin{tabular}{|c|c|c|c|c|}
\hline Tested Fluid & Test Condition & PV (cP) & YP $(\mathbf{l b} / \mathbf{1 0 0 f t} \wedge 2)$ & AV (cP) \\
\hline Base mud + 0.5g WLG & 25 deg.C & 9 & 28 & 23 \\
\hline Base mud $+0.5 \mathrm{~g} \mathrm{WLG}$ & Aged at 85 deg.C for 6 hours then cool to 25 deg.C & 9 & 39 & 29 \\
\hline Base mud $+0.5 \mathrm{~g} \mathrm{CMC}$ & 25 deg.C & 9 & 12 & 15 \\
\hline Base mud $+0.5 \mathrm{~g} \mathrm{CMC}$ & Aged at 85 deg.C for 6 hours then cool to 25 deg.C & 8 & 8 & 12 \\
\hline
\end{tabular}

\subsection{Rheology and Recovery Tests}

For the rheology tests, the viscosity of WLG solution was measured with a torque-type viscometer at varied temperatures and shear rates. Oil recovery experiment was conducted with core flooding equipment. Crude oil sample and rock sample for EOR tests were supplied by a local oil company. The oil specific gravity was 0.86 , and its viscosity was $5.5 \mathrm{cP}$ at $25^{\circ} \mathrm{C}$, and $3.1 \mathrm{cP}$ at $85^{\circ} \mathrm{C}$. A Berea sandstone core was used for recovery experiments. The core sample had relatively good porosity $(20 \%)$ and permeability $(90 \mathrm{mD})$. The rock pore volume was $15.5 \mathrm{~mL}$.

The test matrix is given in Table 2. For the first group of tests, WLG was added to distilled water at different 
concentrations and the viscosity was measured at varied shear rates. For the second group of tests, $\mathrm{NaCl}$ was added to WLG solution to test its tolerance for sodium ions. For the third group of tests, $\mathrm{CaCl}_{2}$ was added to WLG solution to test its tolerance for calcium ions. Fourthly, WLG solution was aged at $85^{\circ} \mathrm{C}$ for 6 hours to test its stability under long term heating.

Finally, core flooding tests were carried out to evaluate WLG's efficiency to enhance oil recovery (EOR). The core flood tests followed standard recovery test procedures [11]. The core was first saturated with brine, and then flooded with crude oil to irreducible water saturation $(S w i)$. The brine contained $150 \mathrm{~g} / \mathrm{L}$ sodium chloride and $50 \mathrm{~g} / \mathrm{L}$ calcium chloride. The same brine was injected afterwards to arrive at residual oil saturation (Sor). The oil recovery by water flooding is thus obtained. The second core flooding test followed the same procedures. But instead of brine, polymer solution containing $1 \mathrm{~g} / \mathrm{L}$ WLG was injected till residual oil saturation.

\section{Experimental Results}

\subsection{Results of Mud Experiments}

Figure 2 presents the base mud viscosity, as well as WLG mud viscosity under varied shear rates. The tests were conducted at room temperature of $25^{\circ} \mathrm{C}$. On this log-log plot, mud viscosity declines almost linearly at higher shear rates. This reveals that mud is a non-Newtonian fluid that abides by the power law. It is also obvious that even a small dosage of WLG leads to significant increase in mud viscosity.

Figure 3 presents the effect of WLG concentration on mud YP (yield point), PV (plastic viscosity), and AV (apparent viscosity) at ambient temperature. Welan gum has a significant impact on mud YP and AV. Mud YP and AV steadily increased with increasing concentration of WLG. Moreover, mud PV also increased with addition of WLG. It can be observed that when WLG concentration increased from 0.75 to $1 \mathrm{~g} / \mathrm{L}$, mud YP increased more sharply from 18 to $28 \mathrm{lb} / 100 \mathrm{ft}^{2}$. This is possibly due to the formation of gel at relatively high WLG concentration.

Figure 4 compares the properties of WLG mud and CMC mud. The addition of CMC resulted in mild increases in mud viscosity and yield point, while WLG is much more effective in boosting mud viscosity. The mud containing $1 \mathrm{~g} / \mathrm{L}$ WLG was heated to $75^{\circ} \mathrm{C}$ for 30 minutes, in order to test the stability of WLG mud at elevated temperature. The test data in Figure 5 shows WLG mud has good stability at high temperature. The mud properties after heating were almost unchanged.

The mud samples were also tested for long-term stability under high temperature. The mud samples aged in a sealed steel cell at $85^{\circ} \mathrm{C}$ for 6 hours, then cooled down to room temperature. Mud properties were measured, and the results are presented in Table 3. For the mud containing WLG, both mud YP and AV increased after aging. This is probably due to the formation of weak gel at high temperature. On the other hand, the mud containing CMC showed reduction in
YP and AV after aging. Comparison shows WLG is resistant to long-term heating.

A good mud thickener must maintain stable viscosity under the attack of sodium and calcium ions. $\mathrm{NaCl}$ and $\mathrm{CaCl}_{2}$ were mixed into WLG mud and the mud properties were measured. The test results are shown in Figure 6 and 7. It can be seen that WLG is resistant to both sodium and calcium ions. The key parameters (YP, AV and PV) all remained quite stable after addition of salts.

\subsection{Results of Rheology and Recovery Experiments}

WLG was mixed into water at varied dosages, and the solution viscosity was measured. Figure 8 presents the effect of WLG concentration on fluid viscosity. These tests were all conducted at $85^{\circ} \mathrm{C}$. The linear trends on log-log plot reveal that WLG solution is a non-Newtonian fluid [12]. It is obvious that WLG effectively boosts viscosity, even at a low concentration. It was also observed that WLG quickly dissolved in water.

Sodium chloride was added to WLG solution containing $8 \mathrm{~g} / \mathrm{L} \mathrm{WLG}$, and the viscosity data is given in Figure 9. It can be seen that sodium ion has certain damaging effect on polymer solution. For example, under shear rate of $10 / \mathrm{s}$, when concentration of sodium chloride increased from 10 to $100 \mathrm{~g} / \mathrm{L}$, the viscosity of WLG solution dropped from 1450 to $1340 \mathrm{cP}$. The viscosity further dropped to $1060 \mathrm{cP}$ when sodium chloride reached $150 \mathrm{~g} / \mathrm{L}$. However, it cannot be denied that the viscosity of WLG still remained high at very high concentration of sodium.

According to a previous study, HPAM is very sensitive to calcium ion [12]. WLG is less sensitive to calcium, as seen in Figure 10. For the tests in Fig. 10, the WLG concentration was $3 \mathrm{~g} / \mathrm{L}$, and no sodium was added. WLG in fresh water demonstrated a viscosity of $252 \mathrm{cP}$ under shear rate of $10 / \mathrm{s}$. After calcium was added, the viscosity declined to $201 \mathrm{cP}$ at the same shear rate. However, the viscosity did not decline further at higher concentration of calcium.

The loss of viscosity at high salinity is a common phenomenon for polymers. It is believed that polymers are relaxed in fresh water, but shrinks and coils at presence of monovalent and divalent ions. Shrinkage of polymer chains leads to reduction in viscosity [2]. According to the results in Figures 9 and 10, welan gum shows excellent resistance to monovalent and divalent ions. This indicates welan gum may be suitable for polymer flooding in high salinity reservoirs.

WLG solution containing $3 \mathrm{~g} / \mathrm{L}$ WLG, $100 \mathrm{~g} / \mathrm{L} \mathrm{NaCl}$ and $50 \mathrm{~g} / \mathrm{L} \mathrm{CaCl} \mathrm{Cl}_{2}$ was sealed in a container at $85^{\circ} \mathrm{C}$ for 6 hours. The viscosity data is presented in Fig. 11. It is clear that viscosity of WLG solution reduced after aging. For instance, at the shear rate of $10 / \mathrm{s}$, viscosity dropped from $175 \mathrm{cP}$ before aging to $125 \mathrm{cP}$ afterwards. This is possibly due to breakage of polymer chains under high temperature. However, WLG solution still maintained relatively high viscosity after aging.

The first recovery test was to establish OOIP and the baseline recovery with water flooding. The injected brine contained $150 \mathrm{~g} / \mathrm{L} \mathrm{NaCl}$ and $50 \mathrm{~g} / \mathrm{L} \mathrm{CaCl}{ }_{2}$. The injection rate was controlled at $0.1 \mathrm{~mL} / \mathrm{min}$. The OOIP was found to be 
$10 \mathrm{~mL}$. After 5 pore volumes of injection, $6 \mathrm{~mL}$ of oil was produced, equivalent to $60 \%$ OOIP. The second test injected WLG solution containing $1 \mathrm{~g} / \mathrm{L}$ WLG at the same injection rate. This low concentration of WLG was chosen because in field projects, oil companies must reduce the costs of chemicals to achieve maximum profits. After injection of 3 pore volumes of polymer fluid, WLG recovered $72 \%$ OOIP. Subsequent injection of WLG fluid did not further improve recovery. This indicates that WLG has positive effects on oil recovery. Injection of WLG also reduces the time required to reach residual oil saturation. Another recent study also confirmed WLG is more effective than HPAM in enhancing oil recovery [13].

It cannot be denied the price of welan gum is much higher than CMC, HEC, and HPAM. However, welan gum demonstrates much better resistance to high salinity and high temperature. On the other hand, welan gum in the market is produced for food industry at a very high grade. Field applications of drilling mud and polymer flooding require lower grade products that cost much less than food grade. Moreover, field implementation will require production of polymers at a large scale, which also helps to reduce the cost of welan gum.

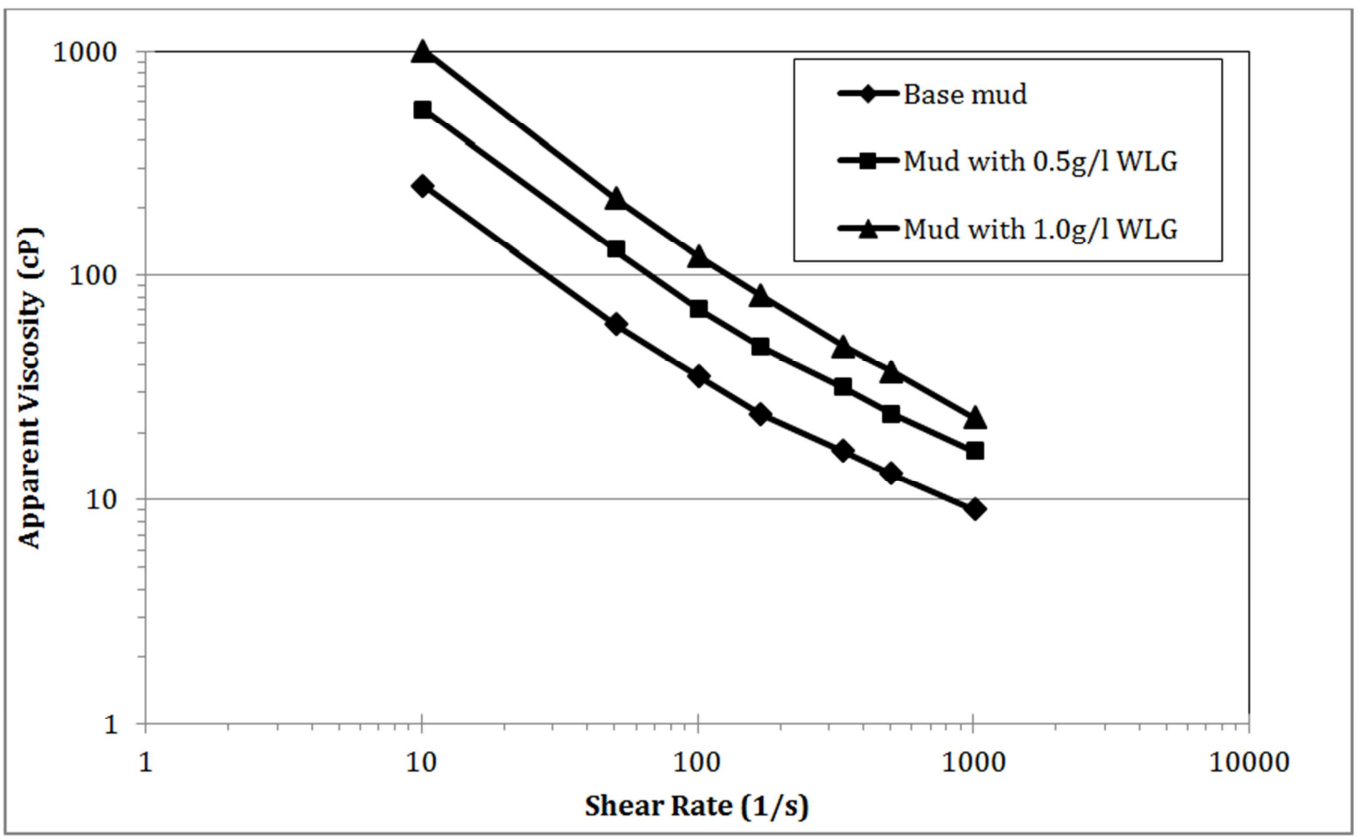

Figure 2. Effect of shear rate and WLG concentration on mud viscosity.

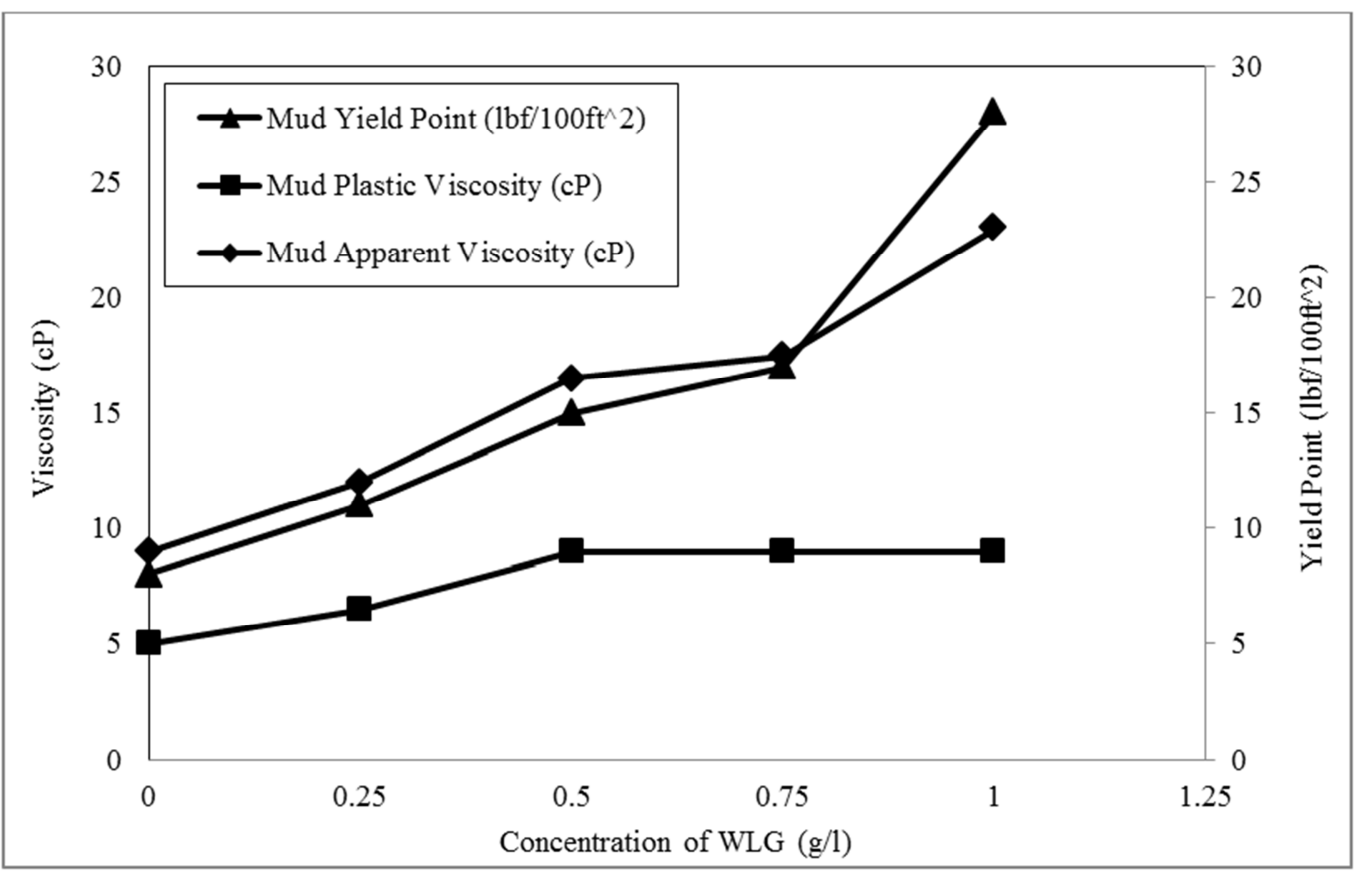

Figure 3. Effect of WLG concentration on mud properties. 


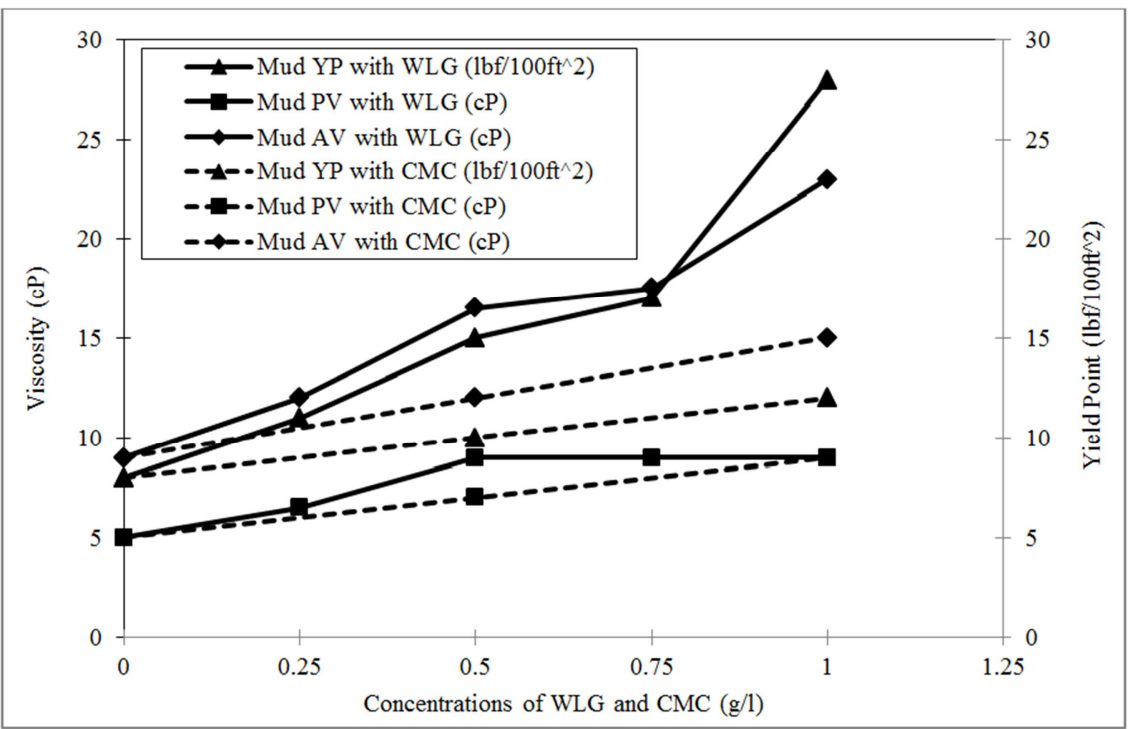

Figure 4. Comparison of properties of WLG mud and CMC mud.

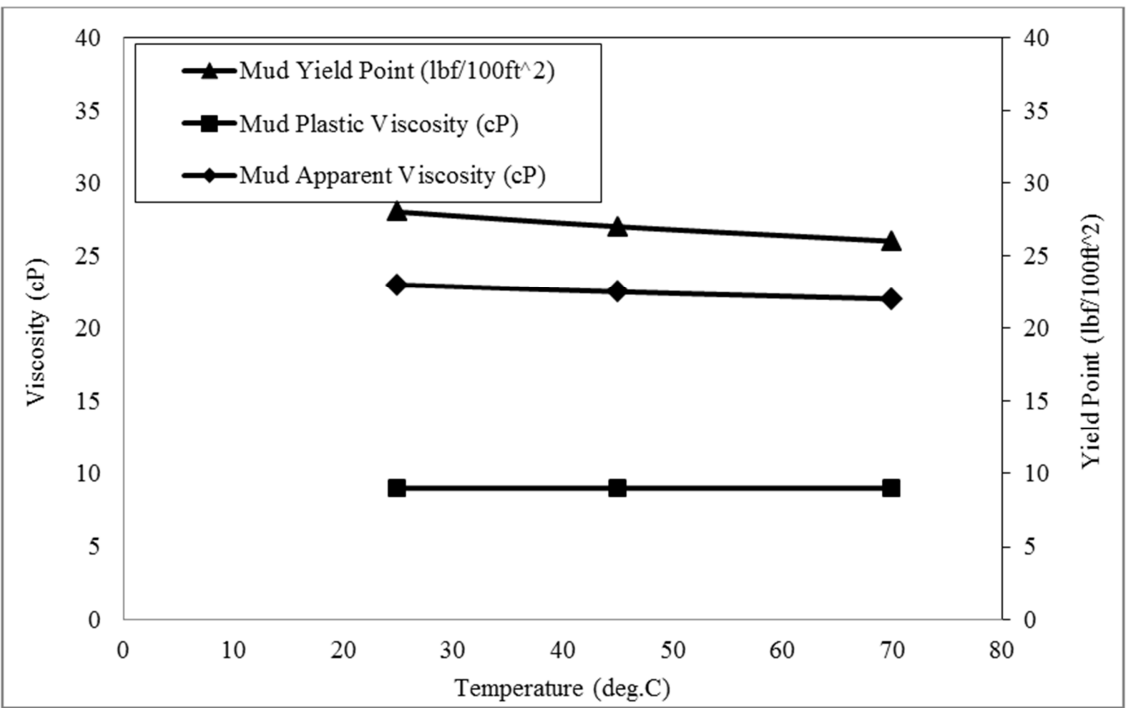

Figure 5. Properties of WLG mud at elevated temperature.

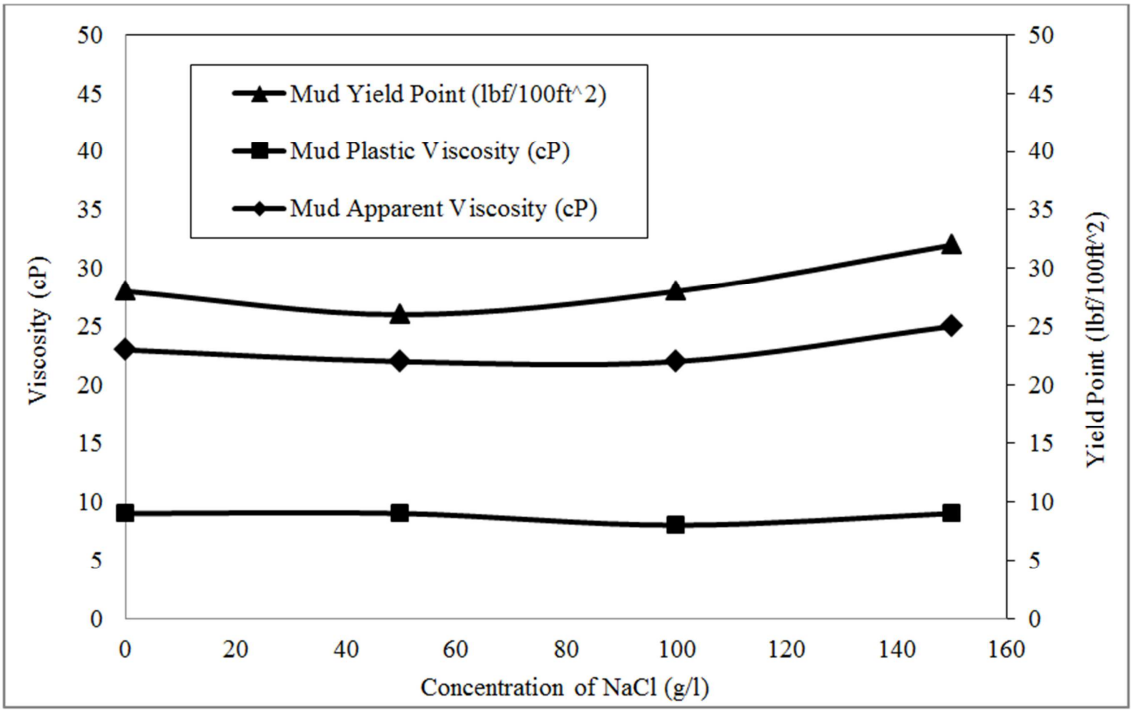

Figure 6. Properties of WLG mud at varied concentrations of $\mathrm{NaCl}$. 


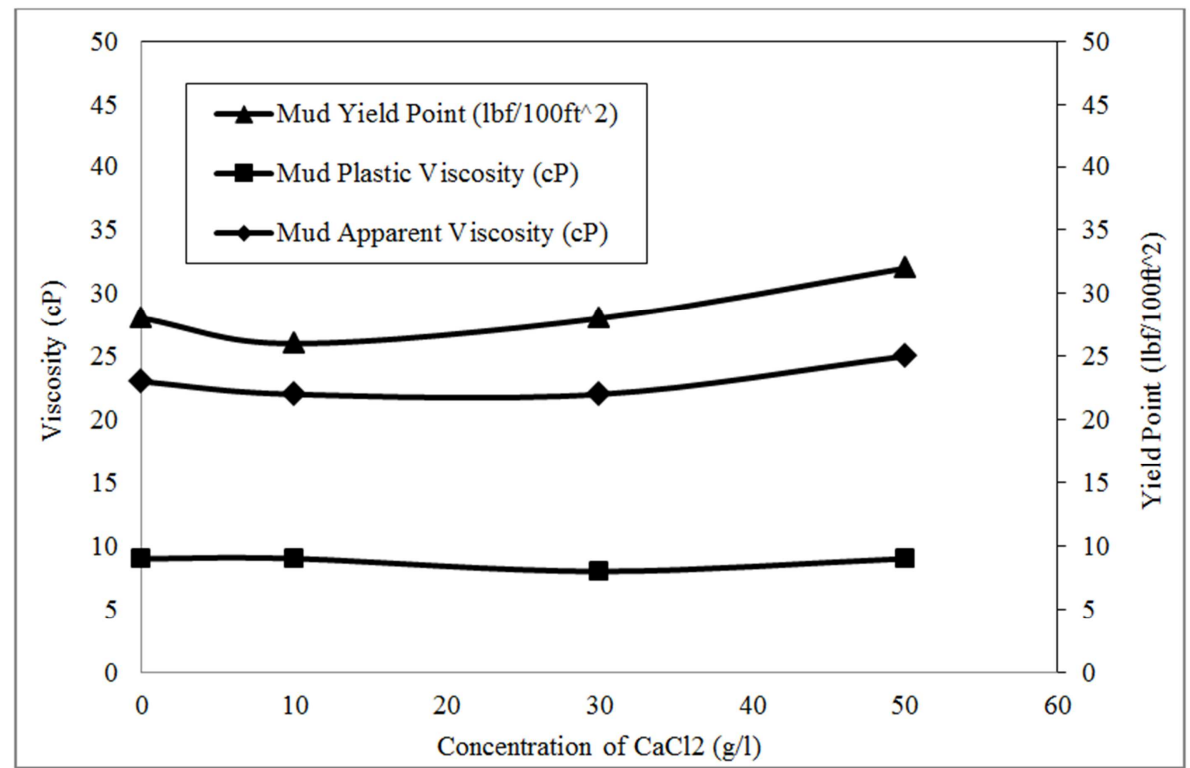

Figure 7. Properties of WLG mud under varied concentrations of $\mathrm{CaCl}_{2}$.

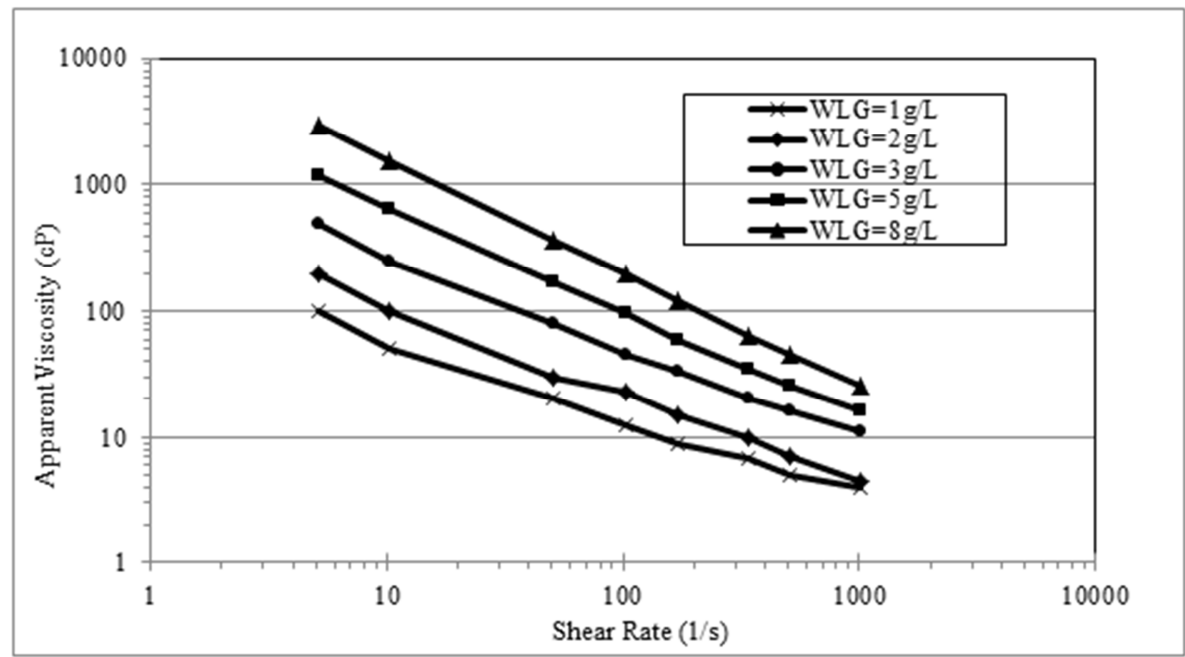

Figure 8. Effect of WLG concentrations on viscosity of WLG solution.

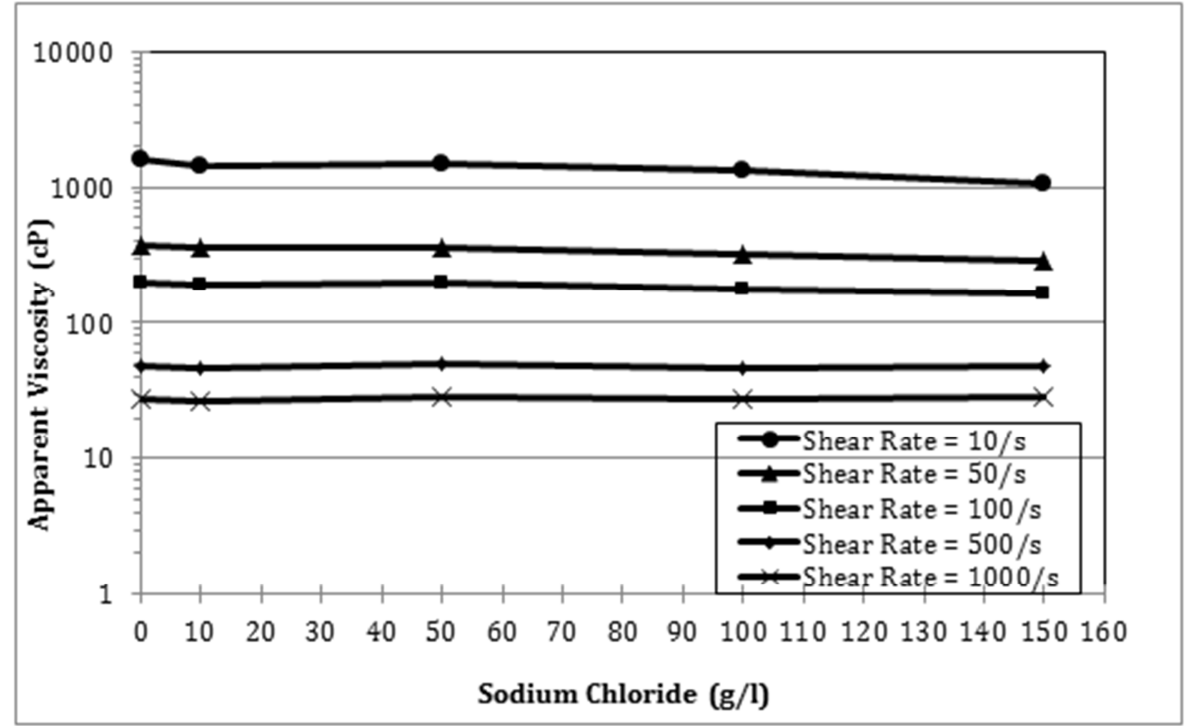

Figure 9. Effect of sodium ion on viscosity of WLG solution. 


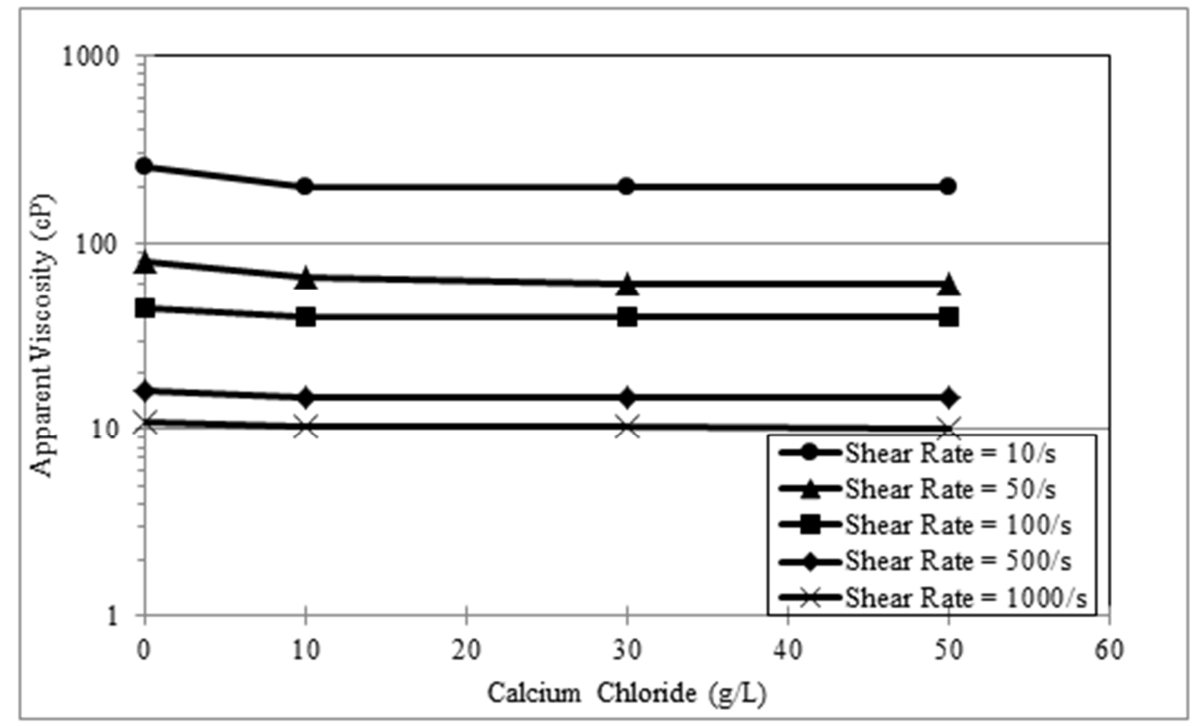

Figure 10. Effect of calcium ion on viscosity of WLG solution.

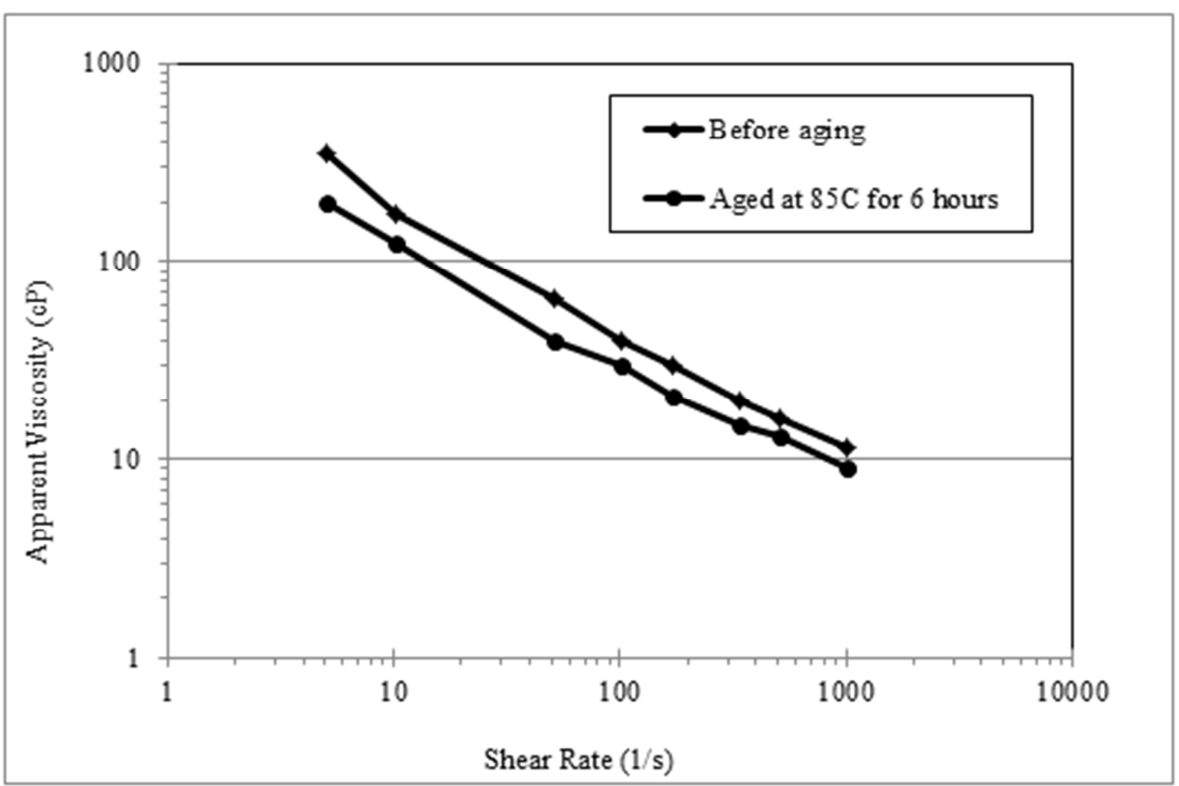

Figure 11. Effect of aging on viscosity of WLG solution.

\section{Conclusions}

(1) Welan gum is very effective in boosting mud viscosity. Mud containing welan gum shows good stability under impacts of monovalent ions, divalent ions, and high temperature. (2) The aqueous solution of welan gum also demonstrates resistance to monovalent ions, divalent ions, and high temperature. Core flooding experiments confirm welan gum has good potential in polymer EOR for high salinity reservoirs.

\section{Acknowledgement}

The author hopes to acknowledge the state of Shandong for providing research fund through Tai Shan Scholar program.

\section{References}

[1] Rabia, H., 1985. Oilwell Drilling Engineering. Graham and Trotman. London, UK. 105-130.

[2] Sheng, J., 2010. Modern Chemical Enhanced Oil Recovery: Theory and Practice. Gulf Professional Publishing. Oxford, UK. 101-111.

[3] Gao, C., Shi, J., Zhao, F., 2014. Successful polymer flooding and surfactant-polymer flooding projects at Shengli Oilfield from 1992 to 2012. Journal of Petroleum Exploration and Production Technology. 4(1), 1-8.

[4] Gao, C., 2011. Scientific research and field applications of polymer flood in heavy oil recovery. Journal of Petroleum Exploration and Production Technology. 3(1), 65-70. 
[5] Gao, C., 2013. Viscosity of partially hydrolyzed polyacrylamide under shearing and heat. Journal of Petroleum Exploration and Production Technology. 3(3), 203-206.

[6] Rakitsky, W., Richey, D., 1992. Rapidly hydrating Welan gum. United States Patent 5175277.

[7] Chen, F., 2007. Study of factors affecting property of Welan gum solution. Food Science. 28 (9), 49-52.

[8] Allen, F., Best, G., Lindroth, T., 1991. Welan gum in cement compositions. United States Patent 5004506.

[9] Hoskin, D., Mitchell, T., Shu, P., 1991. Oil reservoir permeability profile control with cross linked welan gum biopolymers. United States Patent 4991652.
[10] Bourgoyne, A., Chenevert, M., Millheim, K., Yang, F., 1986. Applied Drilling Engineering. SPE Textbook Series. Richardson, USA. 40-50.

[11] Gao, C., Bellout, A., 2013. An Evaluation for Two Bacillus Strains in Improving Oil Recovery in Carbonate Reservoirs. Petroleum Science and Technology. 31(11), 1168-1174.

[12] Gao, C., 2014. Empirical correlations for viscosity of partially hydrolyzed Polyacrylamide. Journal of Petroleum Exploration and Production Technology. 4(2), 209-213.

[13] Xu, L., Xu, G., Yu, L., Gong, H., Dong, M., 2014. The displacement efficiency and rheology of welan gum for enhanced oil recovery. Polymers for Advanced Technologies. DOI: $10.1002 /$ pat.3364. 